\title{
Modern Inhalational Anesthetics for Refractory Status Epilepticus
}

\author{
Frederick A. Zeiler, Kaitlin J. Zeiler, Jeanne Teitelbaum, Lawrence M. Gillman, \\ Michael West
}

\begin{abstract}
Background: Our goal was to perform a systematic review of the literature on the use of modern inhalational anesthetic agents for refractory status epilepticus and their impact on seizure control. Methods: All articles from MEDLINE, BIOSIS, EMBASE, Global Health, HealthStar, Scopus, Cochrane Library, the International Clinical Trials Registry Platform (inception to March 2014), reference lists of relevant articles, and gray literature were searched. The strength of evidence was adjudicated using both the Oxford and Grading of Recommendation Assessment Development and Education methodology by two independent reviewers. Results: Overall, 19 studies were identified, with 16 manuscripts and 3 meeting abstracts. A total of 46 patients were treated. Adult $(\mathrm{n}=28)$ and pediatric patients $(n=18)$ displayed $92.9 \%$ and $94.4 \%$ seizure control with treatment, respectively. Isoflurane was used in the majority of cases. Hypotension was the only complication described. Conclusions: Oxford level 4, Grading of Recommendation Assessment Development and Education D evidence exists to support the use of isoflurane in refractory status epilepticus to obtain burst suppression. Insufficient data exist to comment on the efficacy of desflurane and xenon at this time.
\end{abstract}

RÉSUMÉ: Anesthésiques modernes administrés par inhalation dans le status epilepticus réfractaire au traitement. Contexte: Nous avons effectué une revue systématique de la littérature concernant l'utilisation des anesthésiques modernes administrés par inhalation aux patients en status epilepticus réfractaire au traitement et leur impact sur le contrôle des crises. Méthodes: Nous avons recherché tous les articles pertinents dans MEDLINE, BIOSIS, EMBASE, Global Health, HealthStar, Scopus, Cochrane Library, the International Clinical Trials Registry Platform (de sa création à mars 2014), les listes de références d'articles pertinents ainsi que dans la documentation parallèle. La qualité des études a été déterminée par deux réviseurs indépendants au moyen de deux méthodologies, soit celle du groupe d'Oxford et la Grading of Recommendation Assessment Development and Education. Résultats: Au total, 19 études ont été identifiées dont 16 étaient des manuscrits et 3 étaient des résumés de congrès. Quarante-six patients avaient été traités au moyen d'anesthésiques par inhalation, dont 28 adultes et 18 patients d'âge pédiatrique et chez $92,9 \%$ et 94,4\% d'entre eux respectivement, le traitement a contrôlé le status epilepticus. L'isoflurane a été utilisé dans la majorité des cas. L'hypotension a été la seule complication rapportée. Conclusions: Des données de niveau 4 selon la méthode d'Oxford et de niveau D selon le Grading of Recommendation Assessment Development and Education existent à l'appui de l'utilisation de l'isoflurane chez les patients présentant un status epilepticus réfractaire au traitement pour parvenir à une suppression des salves. Il n'existe pas actuellement suffisamment de données pour évaluer l'efficacité du desflurane ou du xénon.

Keywords: Inhalational anesthetics, volatile anesthetics, status epilepticus

doi:10.1017/cjn.2014.121

Can J Neurol Sci. 2015; 42: 106-115

Refractory status epilepticus (RSE) poses significant challenges for both medical and surgical management. ${ }^{1-3}$ The standard frontline medications used for control of shorter duration seizures, and those patients in status epilepticus, are commonly ineffective in the setting of RSE. ${ }^{3}$

Changes in gamma aminobutyric acid-A $\left(\mathrm{GABA}_{\mathrm{A}}\right)$ receptors leads to unresponsiveness to GABA-mediated medications. ${ }^{4-6}$ Upregulation of p-glycoprotein leads to rapid export of phenytoin and phenobarbital molecules, impairing the action of these antiepileptic drugs (AEDs). ${ }^{7,8}$ In addition, significant upregulation of $\mathrm{N}$-methyl D-aspartate receptors with prolonged seizures leads to glutamate mediated excitoxicity, further potentiating epileptic activity. All of these described mechanisms are thought to be time-dependent. ${ }^{9}$

Thus, the rapid control of seizure activity in RSE is paramount. Numerous emerging therapies for those patients with RSE include but are not limited to therapeutic hypothermia, electroconvulsive therapy, and ketamine.
A potential last resort in RSE has been the use of volatile inhalational anesthetic agents to provide general anesthesia and suppress cortical activity. Few studies exist in the literature focusing on the use of modern inhalational anesthetics for control of refractory seizures. ${ }^{10-28}$

The goal of our study was to perform a systematic review of the literature on the effectiveness of modern inhalational anesthetic agents in controlling refractory seizures.

From the Section of Neurosurgery, Department of Surgery (FAZ, MW), University of Manitoba, Winnipeg, Canada; Section of Neurocritical Care (FAZ, KJZ, JT), Montreal Neurological Institute, McGill, Montreal, Canada; Section of Neurology (JT), Montrea Neurological Institute, McGill, Montreal, Canada; Section of Critical Care Medicine, Department of Medicine (LMG), University of Manitoba, Winnipeg, Canada; Section of General Surgery, Department of Surgery (LMG), University of Manitoba, Winnipeg, Canada.

Received May 9, 2014. Final Revisions Submitted November 21, 2014. Correspondence to: Frederick A. Zeiler, GB-1 820 Sherbrook Street, Health Sciences Center, Winnipeg, Manitoba, Canada R3A1R9. Email: umzeiler@cc.umanitoba.ca 


\section{METHODS}

A systematic review using the methodology outlined in the Cochrane Handbook for Systematic Reviewers ${ }^{29}$ was conducted. The data were reported following the Preferred Reporting Items for Systematic Reviews and Meta-Analyses. ${ }^{30}$ The review questions and search strategy were decided upon by the primary author and supervisor.

\section{Search Question, Population, and Inclusion and Exclusion Criteria}

The question posed for systematic review was: What is the effectiveness of modern inhaled anesthetic gas on control of RSE in humans? All studies, prospective and retrospective of any size based on human subjects, were included. The reason for an all-inclusive search was based on the small number of studies of any type identified by the primary author during a preliminary search of MEDLINE.

The primary outcome measure was electrographic seizure control, defined as: excellent (100\% of patient response), moderate (greater than $50 \%$ of patient response), mild (less than $50 \%$ of patient response), and failure ( $0 \%$ response). This qualitative seizure response grading was used given the heterogeneous treatment response data on electrographic seizure control reported within the studies found. Secondary outcome measures were patient outcome (if reported), and adverse effects of the inhalational anesthetics.

Inclusion criteria were: All studies including human subjects whether prospective or retrospective, all study sizes, any age category, and the use of modern inhalational anesthetic gases (sevoflurane, isoflurane, desflurane, xenon) for seizure control in RSE. Exclusion criteria were: animal and non-English studies and treatment with the inhalational gases other than those mentioned in the inclusion criteria.

\section{Search Strategy}

MEDLINE, BIOSIS, EMBASE, Global Health, HealthStar, SCOPUS, and Cochrane Library from inception to March 2014 were searched using individualized search strategies for each database. The search strategy for MEDLINE can be seen in Appendix A of the supplementary material, with a similar search strategy used for the other databases. In addition, the World Health Organization's International Clinical Trials Registry Platform was searched looking for studies planned or under way.

As well, meeting proceedings for the past ten years looking for ongoing and unpublished work based on inhalational anesthetics for seizures were examined. The meeting proceedings of the following professional societies were searched: Canadian Neurological Sciences Federation, American Association of Neurological Surgeons, Congress of Neurological Surgeons, European Neurosurgical Society, World Federation of Neurological Surgeons, American Neurology Association, American Academy of Neurology, European Federation of Neurological Science, World Congress of Neurology, Society of Critical Care Medicine, Neurocritical Care Society, World Federation of Societies of Intensive and Critical Care Medicine, American Epilepsy Society, the International League Against Epilepsy, American Society for Anesthesiologists, World Federation of Societies of Anesthesiologist, Australian Society of Anesthesiologists, International Anesthesia Research
Society, Society of Neurosurgical Anesthesiology and Critical Care, Society for Neuroscience in Anesthesiology and Critical Care, and the Japanese Society of Neuroanesthesia and Critical Care.

Finally, reference lists of any review articles or systematic reviews on seizure management were hand-searched for relevant studies on inhalational anesthetic usage for seizure control.

\section{Study Selection}

Using two reviewers (FZ and MW), a two-step review of all articles returned by our search strategies was performed. First, the reviewers independently screened all titles and abstracts of the returned articles to decide if they met the inclusion criteria. Second, the full text of the chosen articles was then assessed to confirm if they met the inclusion criteria and that the primary outcome of seizure control was reported in the study. Any discrepancies between the two reviewers were resolved by a third party (JT or LG).

\section{Data Collection}

Data were extracted from the selected articles and stored in an electronic database. Data fields included: patient demographics, type of study (prospective or retrospective), number of patients, type of anesthetic gas used, dose of anesthetic gas used, timing to administration of drug, duration of drug administration, time to effect of drug, how many other AEDs were used before implementation of inhalational anesthetic gas, degree of seizure control (as described previously), adverse effects, and patient outcome.

\section{Quality of Evidence Assessment}

Assessment of the level of evidence for each included study was conducted by an interdisciplinary panel of three independent reviewers using the Oxford criteria ${ }^{31}$ and the Grading of Recommendation Assessment Development and Education (GRADE) criteria $^{32-37}$ for level of evidence. We elected to use two different systems to grade level of evidence given that these two systems are among the most commonly used. We believe this would allow a larger audience to follow our systematic approach in the setting of unfamiliarity with a particular grading system.

The Oxford criteria consist of a five-level grading system for literature. Level 1 is split into subcategories $1 \mathrm{a}, 1 \mathrm{~b}$, and $1 \mathrm{c}$, which represent a systematic review of randomized control trials (RCTs) with homogeneity, individual RCTs with narrow confidence interval, and all or none studies, respectively. Oxford level 2 is split into $2 \mathrm{a}, 2 \mathrm{~b}$, and $2 \mathrm{c}$, representing systematic review of cohort studies with homogeneity of data, individual cohort study or low-quality RCTs, and outcomes research, respectively. Oxford level 3 is split into $3 a$ and $3 b$, representing systematic review of case-control studies with homogeneity of data and individual case-control study, respectively. Oxford level 4 represents case series and poor cohort studies. Finally, Oxford level 5 represents expert opinion.

The GRADE level of evidence is split into four levels: A, B, C, and D. GRADE level A represents high evidence with multiple high-quality studies having consistent results. GRADE level B represents moderate evidence with one high-quality study or multiple low-quality studies. GRADE level C evidence represents low evidence with one or more studies with severe limitations. 


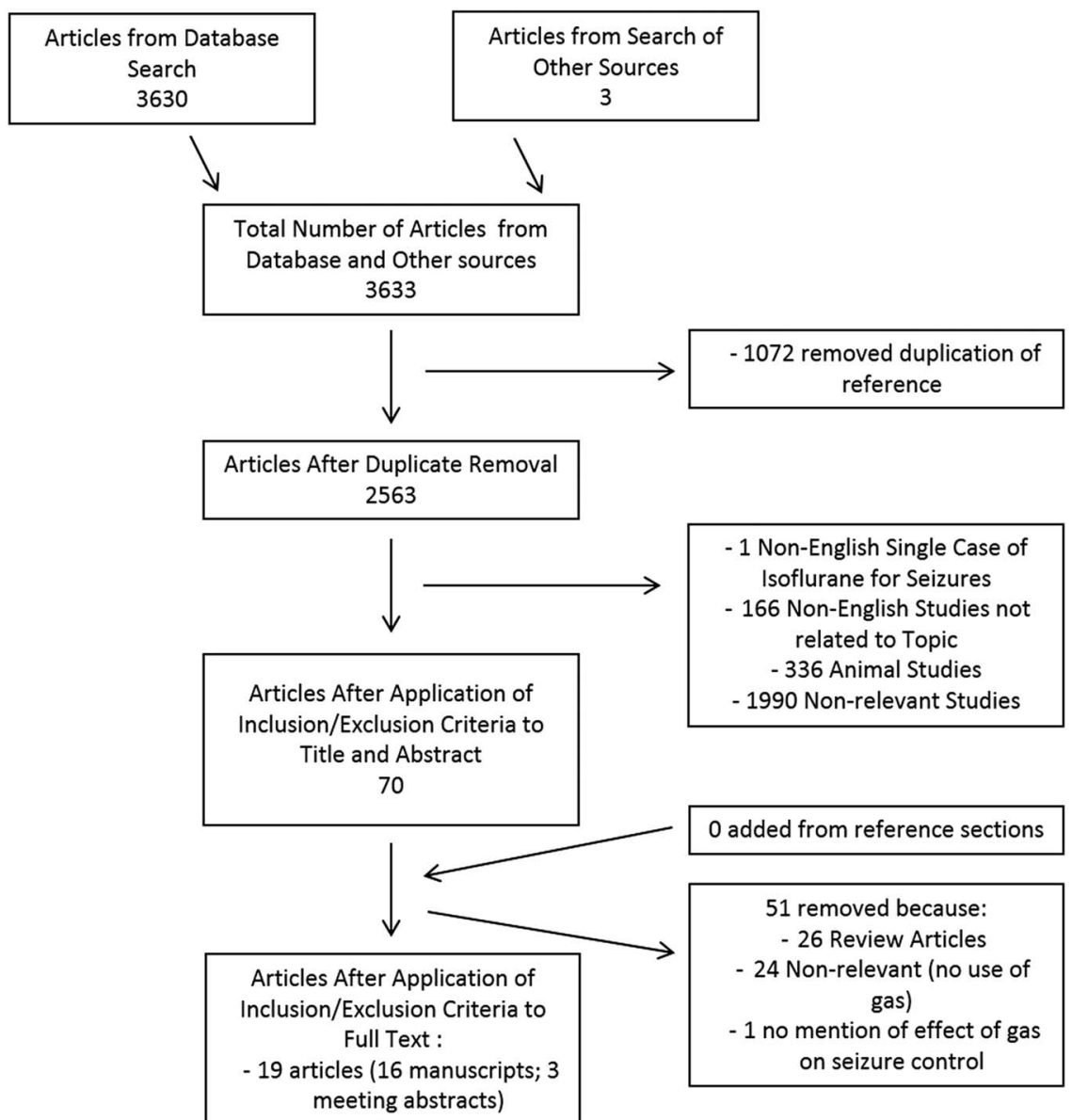

Figure 1: Flow diagram of search results

Finally, GRADE level D represents very low evidence based on either expert opinion or few studies with severe limitations.

Any discrepancies between the grading of the three reviewers were resolved by a fourth reviewer.

\section{Statistical Analysis}

A meta-analysis was not performed in this study because of the heterogeneity of data within the articles and the presence of a small number of low-quality retrospective studies.

\section{RESULTS}

The results of the search strategy across all databases and other sources are summarized in Figure 1. Overall, 3633 articles were identified, with 3630 from the database search and 3 from the search of published meeting proceedings. After removing duplicate references, there were 2563 articles. By applying the inclusion/exclusion criteria to the title and abstract of the articles, we identified 70 articles that fit these criteria. Of the 70 identified, 67 were from the database search and 3 were from published meeting proceedings. Applying the inclusion/exclusion criteria to the full text documents, only 19 articles were eligible for inclusion in the systematic review, with 16 from database and 3 from meeting proceeding sources. The 51 articles that were excluded were done so because they either did not report details around the administration of inhaled anesthetic agents for seizure control, or because they were review articles. Reference sections from these review articles were searched by hand for any other articles missed in the database search, with none being identified.

Of the 19 articles included in the review, ${ }^{10-28}$ all were original studies. Kofke et $\mathrm{al}^{18}$ included patient data from 2 of the other 19 articles. ${ }^{17,25}$ Similarly, Kofke et $\mathrm{al}^{19}$ contained data from 1 of the 19 articles. $^{17}$ The patient data repeated in these two studies ${ }^{17,25}$ were not included in the tabulation of data for this review in order to avoid including the same individual patient data multiple times. Three articles were published meeting abstracts. ${ }^{12,18,27}$

There were 18 retrospective studies ${ }^{10,12-28}$ and 1 prospective study. ${ }^{11}$ Thus the potential for significant publication bias is present. Within the retrospective studies, eight were retrospective case series ${ }^{10,12,17-19,23,26,27}$ and the remaining ten were retrospective case reports. ${ }^{13-16,20-22,24,25,28}$ The retrospective case series were composed of six single-center reviews ${ }^{10,12,17,23,26,27}$ and two multicenter reviews. ${ }^{18,19}$ The one prospective study included in the systematic review was a prospective cohort study with no control group. ${ }^{11}$ Fourteen articles described the use of inhaled anesthetic in adults, ${ }^{13-16,18-20,22-28}$ with Ropper et $\mathrm{al}^{25}$ containing duplicate patient data. Nine studies described pediatric patients, ${ }^{10-13,17-19,21,23}$ with one containing duplicated data. ${ }^{17}$ Four of the 19 studies have combined adult and pediatric patient populatons, ${ }^{13,18,19,23}$ with Kofke et al ${ }^{18}$ not 
separating adult from pediatric data and thus being included in the adult summary.

Four different inhalational anesthetic agents were reported. Isoflurane was used in 18 studies, ${ }^{10,12-28}$ desflurane in $2,{ }^{23,28}$ and xenon in $1 .{ }^{11}$ Halothane was used in two studies, ${ }^{12,25}$ but its effect was not analyzed given its current lack of use as a modern anesthetic gas.

Across all studies, 46 patients were studied using modern inhalational anesthetic gas for control of their seizures (mean 2.4 patients/study; range: 1-9 patients/study). Eighteen patients were pediatric (age range: 8 months to 17 years), with the exclusion of data from Kofke et al ${ }^{18}$ because adult and pediatric data were not separated within the abstract. Twenty-eight patients were adult (age range: 18-71 years). A variety of underlying etiologies for RSE existed in both the adult and pediatric populations.

Study demographics and patient characteristics for all studies can be seen in Table 1, whereas treatment characteristics and seizure outcome are reported in Table 2.

\section{Inhalational Anesthetic Treatment Characteristics}

\section{Adults}

The literature on inhaled anesthetics for seizure control in the adult population yielded 13 studies with original patient data. Ropper et $\mathrm{al}^{25}$ was not included in the adult summary because of data duplication. Within these 13 studies, ${ }^{13-16,18-20,22-24,26-28} 11$ used isoflurane only ${ }^{13-16,18-20.22,24,26,27}$ with a minimum alveolar concentration (MAC) ranging from 0.5 to $5.0 \%$ (commonly used dose across all studies was $0.5-2.0 \%$ ). One study ${ }^{23}$ used isoflurane in isolation at a MAC ranging from 0.5 to $5.0 \%$ in five patients, and a combination of desflurane/isoflurane with a MAC of $1.0-4.0 \% / 0.1-0.66 \%$ for one patient. The final study for adults used desflurane for 13 days, followed by isoflurane for 13 days at a MAC of $1.0-4.0 \%$ and 0.1 and $0.66 \%$, respectively. ${ }^{28}$

Duration of treatment before inhalational anesthetic administration was documented in nine adult studies, ranging from 8 hours to 60 days (median $=45$ hours), with patients on various numbers of AEDs before anesthetic gas, ranging from 1 to 15 (mean $=6.8$, median $=7$ ). Similarly, the duration of inhaled anesthetic treatment was described in 10 of the 13 adults studies, with treatment duration ranging from 5 hours to 32 days (median $=$ 30.3 hours, mean $=112.0$ hours). Treatment characteristics for the adult studies can be seen in Table 2 .

\section{Pediatrics}

Within those nine studies describing inhaled anesthetic use in the pediatric population, ${ }^{10-13,17-19,21,23}$ one study was not included because of duplication of patient data, ${ }^{17}$ whereas a second study ${ }^{18}$ failed to separate pediatric from adult data and thus had its data included in the adult section of the review. Among the seven remaining studies, isoflurane was use in isolation in five $\operatorname{articles}^{10,13,19,21,23}$ with a MAC of $0.5-5.0 \%$ (usual range= $0.5-2.5 \%$ ). One study used halothane and isoflurane at unknown concentrations. ${ }^{12}$ Finally, one study focused on xenon anesthetic in asphyxial neonates at a concentration of $30 \% .^{11}$

Duration of treatment before inhalational anesthetic administration was documented in five pediatric studies, ranging from 12 hours to 103 days (median $=312$ hours), with patients on various numbers of AEDs before ketamine, ranging from 0 to 10
( median $=4$, mean $=5$ ). Similarly, the duration of inhaled anesthetic treatment was described in four studies, ranging from 1 hour to 85 days (median $=29$ hours). Treatment characteristics for the pediatric studies can be seen in Table 2 .

\section{Seizure Response}

\section{Adults}

Seizure control upon inhaled anesthetic administration in the adult population was documented as excellent (complete response in all patients) in 12 of 14 studies, taking into account duplicate patient data. Failure of treatment response in all patients occurred in two studies with a total of two patients within these studies. ${ }^{24,27}$

Across all 13 adult studies, with nonduplicate patient data, a total of 26 of 28 adult patients $(92.9 \%)$ were described as having complete electrographic seizure responsiveness to inhalational anesthetics, namely isoflurane. Isoflurane was effective in all but two patients $(7.7 \%)$ when used as the only inhaled anesthetic. ${ }^{24,27}$ The timing of electrographic response to isoflurane anesthesia was described as "immediate" in all 26 adult patients that demonstrated a response, typically within minutes when documented. An unspecified majority of patients required titration of the isoflurane MAC to achieve burst suppression.

Desflurane was inferior to isoflurane in controlling seizure activity and achieving burst suppression in the two adult patients within which it was used. ${ }^{23,28}$ Desflurane achieved seizure reduction in the two adult studies, but burst suppression was not achieved, even with MAC reaching 4.0\%. Isoflurane was used as a salvage agent to achieve seizure control in these two studies.

Regardless of the inhaled anesthetic used, seizure activity tended to return upon cessation of the volatile gas treatment.

\section{Pediatrics}

Seizure control in the pediatric studies, with nonduplicate patient data, was documented as excellent in six of the seven studies. $^{11-13,17,19,21,23}$ A total of 17 of 18 pediatric patients (94.4\%) had seizure control with inhalational treatment. Failure of treatment response was described in one pediatric patient $(5.6 \%) .{ }^{10}$

Isoflurane failed to control the refractory seizures in 1 of 13 patients $(7.7 \%)$ in which it was used. This patient had suspected Rasmussen's encephalitis, ${ }^{10}$ requiring surgical intervention to halt seizure activity. The timing to response of seizures to isoflurane in children was typically immediate, but required titration to achieve burst suppression. As in the adult population, cessation of isoflurane seemed to precipitate seizures in most patients.

Xenon was used in asphyxial neonates and displayed excellent results in the five children with seizures. ${ }^{11}$ Seizures seemed to return with cessation of xenon.

\section{Adverse Effects of Inhalational Anesthetics}

Adverse effects were seldom described within the 19 articles reviewed. Four studies described hypotension temporally associated to isoflurane treatment and required vasopressors. ${ }^{19,21,26,28}$ Finally, one study ${ }^{13}$ described nonspecific MRI changes in the cerebellum and thalamus potentially attributable to long-term isoflurane administration of more than 30 days. However, these changes occurred in the setting of severe RSE and may not reflect anesthetic gas treatment. 
Table 1: Study characteristics and patient demographics

\begin{tabular}{|c|c|c|c|c|c|c|c|c|}
\hline Reference & $\begin{array}{l}\text { Number of patients } \\
\text { treated with } \\
\text { anesthetic gas }\end{array}$ & Study type & Study setting & Article location & Mean age (y) & Etiology of seizures & $\begin{array}{c}\text { Mean no. of } \\
\text { medications } \\
\text { before anesthetic } \\
\text { gas }\end{array}$ & $\begin{array}{l}\text { Mean time until } \\
\text { anesthetic gas } \\
\text { administration } \\
\text { (d) }\end{array}$ \\
\hline Alexopolous et $\mathrm{al}^{10}$ & $\begin{array}{c}10 \\
\text { (only } 1 \text { had inhala- } \\
\text { tional treatment) }\end{array}$ & Retrospective case series & Single center & Manuscript & 22 months & Possible Rasmussen's encephalitis & 4 & Unknown \\
\hline Azzopardi et $\mathrm{al}^{11}$ & $\begin{array}{c}14 \\
\text { (only } 5 \text { had seizures) }\end{array}$ & Prospective cohort & Multicenter & Manuscript & $\begin{array}{c}\text { Neonates: } 36-43 \mathrm{wk} \\
\text { GA }\end{array}$ & Asphyxial encephalopathy & $\begin{array}{c}0 \\
72 \mathrm{~h} \text { of hypother- } \\
\text { mia concurrently }\end{array}$ & $\begin{array}{l}\text { Within } 12 \mathrm{~h} \text { of } \\
\text { birth }\end{array}$ \\
\hline Demulder et $\mathrm{al}^{12}$ & 3 & Retrospective case series & Single center & Meeting abstract & $5-9$ & Pearson syndrome & 8 & Unknown \\
\hline Fugate et $\mathrm{al}^{13}$ & 2 & Retrospective case series & Single center & Manuscript & 25 and 4 & Idiopathic in both & $\begin{array}{l}5 \text { and } 7 \text { (plus } \\
\text { ketogenic diet) }\end{array}$ & 5 and 13 \\
\hline Hilz et al ${ }^{14}$ & 1 & Retrospective case Report & Single Center & Manuscript & 35 & $\begin{array}{l}\text { Epilepsy since birth. noncompliant } \\
\text { with medications }\end{array}$ & 5 & Unknown \\
\hline Hilz et $\mathrm{al}^{15}$ & 1 & Retrospective case report & Single center & Manuscript & 28 & Thallium poisoning & 4 & 6 \\
\hline Hughes et $\mathrm{al}^{16}$ & 1 & Retrospective case report & Single center & Manuscript & 30 & Chronic encephalitis & 7 & $2 \mathrm{mo}$ \\
\hline Kofke et $\mathrm{al}^{17^{*}}$ & 1 & Retrospective case report & Single center & Manuscript & 10 & Viral encephalitis & 5 & 27 \\
\hline Kofke et al ${ }^{18^{*}}$ & 6 & Retrospective case series & Multicenter & Meeting abstract & Range: $2-30$ & $\begin{array}{l}\text { Idiopathic (2); viral encephalitis (2); } \\
\text { AVM (1); organophosphates (1) }\end{array}$ & 3 & Unknown \\
\hline Kofke et al ${ }^{19 \dagger}$ & $\begin{array}{c}9 \\
\text { (11 occasion of } \\
\text { RSE) }\end{array}$ & Retrospective Case series & Multicenter & Manuscript & 28.5 (range: $2-64$ ) & $\begin{array}{l}\text { Idiopathic (5); AVM (2); Aneurysm } \\
\text { clipping (1); organophosphates (1); } \\
\text { post liver transplant (1); bacterial } \\
\text { meningitis (1) }\end{array}$ & 2 (range: $1-11$ ) & $\begin{array}{l}17.5 \text { (range: } 8 \mathrm{~h}- \\
40 \mathrm{~d} \text { ) }\end{array}$ \\
\hline Kofke et al ${ }^{20}$ & 1 & Retrospective case report & Single center & Manuscript & 21 & Idiopathic & 9 & $44 \mathrm{~h}$ \\
\hline Lippert et $\mathrm{al}^{21}$ & 1 & Retrospective case report & Single center & Manuscript & $8 \mathrm{mo}$ & $\begin{array}{l}\text { Known epilepsy, noncompliant with } \\
\text { medications given gastroenteritis }\end{array}$ & 4 & 2 \\
\hline Meeke et $\mathrm{al}^{22}$ & 1 & Retrospective case report & Single center & Manuscript & 32 & Known epilepsy, CP & 8 & 3 \\
\hline Mirsattari et $\mathrm{al}^{23}$ & 7 & Retrospective case series & Single center & Manuscript & 42.4 (range: $17-71$ ) & $\begin{array}{l}\text { Cryptogenic (2); silver toxicity (1); } \\
\text { noncompliance (1); encephalitis } \\
\text { (1); hemorrhage leukoencephalitis } \\
\text { (1); ODG (1) }\end{array}$ & 10 (range: $7-15$ ) & 19 (range: $1-103$ ) \\
\hline Robakis et $\mathrm{al}^{24}$ & 1 & Retrospective case report & Single center & Manuscript & 30 & Idiopathic & 13 & Unknown \\
\hline Ropper et al ${ }^{25^{*}}$ & 1 & Retrospective case report & Single center & Manuscript & 29 & Encephalitis & 8 & 32 \\
\hline Sakaki et al ${ }^{26}$ & 4 & Retrospective case series & Single center & Manuscript & 35.3 (range: $24-44$ ) & Post-resection: tumor (2); AVM (2) & 3 (range: $3-5$ ) & Unknown \\
\hline Savard et $\mathrm{al}^{27}$ & 1 & Retrospective case series & Single center & Meeting abstract & 27 & POLG mitochondrial disorder & 13 (plus ECT) & Unknown \\
\hline Sharpe et $\mathrm{al}^{28}$ & 1 & Retrospective case report & Single center & Manuscript & 71 & Idiopathic & 7 & $24 \mathrm{~h}$ \\
\hline
\end{tabular}

${ }^{*}$ Kofke et $\mathrm{al}^{18}$ is a meeting abstract that reports the case from Kofke et al ${ }^{17}$ and Ropper et al ${ }^{25}$; patient data from Kofke et al and Ropper et al ${ }^{25}$ were not included in the tabulation of results in order to avoid duplication of patient data.

${ }^{\dagger}$ Kofke et al ${ }^{19}$ contains the patient data from Kofke et $\mathrm{al}^{17}$ as well.

$\mathrm{AVM}=$ arteriovenous malformation; $\mathrm{CP}=$ cerebral palsy; $\mathrm{ECT}=$ electroconvulsive therapy; $\mathrm{ODG}=$ oligodendroglioma. 
Table 2: Treatment characteristics, seizure response, and outcome

\begin{tabular}{|c|c|c|c|c|c|c|c|c|}
\hline Reference & $\begin{array}{l}\text { Anesthetic gas } \\
\text { used }\end{array}$ & Anesthetic gas dose & $\operatorname{MAC}(\mathbf{h})$ & $\begin{array}{l}\text { Mean duration of } \\
\text { anesthetic gas (d) }\end{array}$ & Electrographic seizure response & $\begin{array}{l}\text { Rating of } \\
\text { seizure } \\
\text { response }\end{array}$ & Adverse effects to ketamine & Patient outcome \\
\hline $\begin{array}{l}\text { Alexopolous } \\
\text { et al }^{10}\end{array}$ & Isoflurane & Unknown & Unknown & Unknown & No Response & Failed & Not described & $\begin{array}{l}\text { Required surgery for seizure } \\
\text { reduction }\end{array}$ \\
\hline $\begin{array}{l}\text { Azzopardi } \\
\text { et al }{ }^{11}\end{array}$ & Xenon & $30 \%$ & Unknown & 1 & $\begin{array}{l}\text { All stopped with xenon, recurrence } \\
\text { with cessation of therapy }\end{array}$ & Excellent & Not described & Unknown \\
\hline $\begin{array}{c}\text { Demulder } \\
\text { et al }^{12}\end{array}$ & $\begin{array}{l}\text { Halothane and } \\
\text { isoflurane }\end{array}$ & Unknown & Unknown & Unknown & $\begin{array}{c}\text { Immediate cessation of seizures } \\
\text { (returned after stopping gas) }\end{array}$ & Excellent & Not described & Unknown \\
\hline Fugate et al ${ }^{13}$ & Isoflurane & $\begin{array}{l}\text { MAC }=1 \% \\
\quad \text { titrated to burst suppression } \\
\quad \text { (range: } 0.5-2.5 \% \text { ) }\end{array}$ & 1382.4 and 1975.2 & 34 and 85 & Burst suppression achieved & Excellent & $\begin{array}{l}\text { Potential FLAIR } \\
\text { hyperintensity in } \\
\text { cerebellum and thalamus } \\
\text { related to treatment } \\
\text { duration }\end{array}$ & $\begin{array}{l}\text { Vegetative state and } \\
\text { minimally conscious }\end{array}$ \\
\hline Hilz et $\mathrm{al}^{14}$ & Isoflurane & $\begin{array}{l}\mathrm{MAC}=0.5 \% \text { initially, titrated to } \\
1.5 \% \text { to achieve slowing }\end{array}$ & $\begin{array}{l}8.75 \text { (over two } \\
\text { occasions) }\end{array}$ & $6 \mathrm{~h}, 45 \mathrm{~min}$ & $\begin{array}{l}\text { Immediate reduction in seizure } \\
\text { activity }\end{array}$ & Excellent & None & Worse cognitive impairment \\
\hline Hilz et al ${ }^{15}$ & Isoflurane & $\begin{array}{l}\mathrm{MAC}=1.5 \% \text { initially for control, } \\
\text { then titrated to seizures on EEG } \\
\text { Range }(0.8-1.2 \%)\end{array}$ & 168.0 & 7 & $\begin{array}{l}\text { Cessation of seizure within } 4 \mathrm{~min} \\
\text { of therapy (returned with MAC } \\
<0.8 \% \text { ) }\end{array}$ & Excellent & None & Vegetative state \\
\hline $\begin{array}{l}\text { Hughes } \\
\text { et } \mathrm{al}^{16}\end{array}$ & Isoflurane & $\begin{array}{l}\mathrm{MAC}=0.5 \% \\
\quad(\text { maximum } 0.7 \%)\end{array}$ & 24.0 & 2 & Immediate control of seizures & Excellent & None & Discharged home \\
\hline $\begin{array}{l}\text { Kofke } \\
\text { et al. }{ }^{17^{* *}}\end{array}$ & Isoflurane & $\begin{array}{l}\text { MAC }=0.5 \% \text { initially, titrated to } \\
\text { EEG response } \\
\text { (range: } 0.3-1.2 \% \text { ) }\end{array}$ & 24.0 & 2 & Immediate control of seizures & Excellent & None & Discharged home \\
\hline $\begin{array}{l}{ }^{*} \text { Kofke } \\
\text { et al }{ }^{18}\end{array}$ & Isoflurane & $\begin{array}{l}\text { Range: } 0.5-3.0 \% \text { MAC, titrated to } \\
\text { EEG burst suppression }\end{array}$ & Unknown & $31.5 \mathrm{~h}$ (range: $-54 \mathrm{~h}$ ) & Immediate response & Excellent & None & $\begin{array}{l}\text { Uncontrolled seizures off of } \\
\text { isoflurane in } 3 \text { ( } 2 \text { died })\end{array}$ \\
\hline $\begin{array}{l}\text { Kofke } \\
\text { et al }{ }^{19 \dagger}\end{array}$ & Isoflurane & $\begin{array}{l}\text { Range: } 0.5-5 \% \text { MAC, titrated to } \\
\text { burst suppression }\end{array}$ & Unknown & $29 \mathrm{~h}$ (range: $1-55 \mathrm{~h}$ ) & $\begin{array}{l}\text { Immediate response (seizure } \\
\text { reduction then burst } \\
\text { suppression) } \\
\text { SE resumed in } 8 / 11 \text { episodes of } \\
\text { RSE after cessation of } \\
\text { isoflurane }\end{array}$ & Excellent & $\begin{array}{l}\text { Hypotension in all requiring } \\
\text { vasoppressors }\end{array}$ & $\begin{array}{l}6 \text { of } 9 \text { patients died, } 3 \text { severe } \\
\text { cognitive deficits }\end{array}$ \\
\hline Kofke et $\mathrm{al}^{20}$ & Isoflurane & $\begin{array}{l}\text { MAC }=0.5 \% \text { initially, titrated to } \\
\text { EEG }\end{array}$ & Unknown & $7.5 \mathrm{~h}$ & Immediate response & Excellent & None & $\begin{array}{l}\text { Discharged Home, under care } \\
\text { of parents }\end{array}$ \\
\hline $\begin{array}{l}\text { Lippert } \\
\text { et }^{2 a^{21}}\end{array}$ & Isoflurane & $\begin{array}{l}\mathrm{MAC}=1 \% \text { initially, titrated to } \\
\mathrm{EEG}(\max 2.0 \%)\end{array}$ & 1.0 & $1 \mathrm{~h}$ & $\begin{array}{l}\text { Immediate response (burst } \\
\text { suppression, then silent EEG) }\end{array}$ & Excellent & None & Discharged home \\
\hline Meeke et al ${ }^{22}$ & Isoflurane & $\mathrm{MAC}=0.5-1.0 \%$ & 45.0 & $45 \mathrm{~h}$ & Immediate response $(10 \mathrm{~min})$ & Excellent & None & $\begin{array}{l}\text { Died of sepsis day } 53 \text { into ICU } \\
\text { stay }\end{array}$ \\
\hline $\begin{array}{l}\text { Mirsattari } \\
\text { et al }^{23}\end{array}$ & $\begin{array}{l}\text { Isoflurane (7)/ } \\
\text { desflurane (1) }\end{array}$ & $\begin{array}{l}\text { Isoflurane: } \\
\text { Mean maximum MAC }=1.2- \\
5.0 \% \\
\text { Desflurane: } \\
\text { MAC }=1-4 \%\end{array}$ & $\begin{array}{c}173 \pm 159 \text { (range: } \\
12-277 \text { ) }\end{array}$ & $11 \pm 9$ (range: $2-26)$ & $\begin{array}{l}\text { Immediate response (burst } \\
\text { Suppression within minutes) }\end{array}$ & Excellent & $\begin{array}{l}\text { Hypotension requiring } \\
\text { increase in vasopressors }\end{array}$ & $\begin{array}{l}\text { GOS of } 5 \text { in } 2 \text { patient; GOS of } \\
4 \text { in } 2 \text { patients; GOS of } 1 \\
\text { (died) in } 3 \text { patients. }\end{array}$ \\
\hline $\begin{array}{l}\text { Robakis } \\
{\text { et } \mathrm{al}^{24}}^{4}\end{array}$ & Isoflurane & Unknown & Unknown & Unknown & No response & Failed & Unknown & Persistent vegetative state \\
\hline $\begin{array}{l}\text { Ropper } \\
\text { et al }^{25^{*}}\end{array}$ & $\begin{array}{l}\text { Nitrous oxide/ } \\
\text { halothane } \\
\text { trial } \times 1\end{array}$ & $\begin{array}{l}\text { Nitrous oxide/halothane: } \\
\quad(60 \% .1 .25 \%) \\
\text { Isoflurane: } \\
\text { Range: } 0.25-2.0 \% \text { MAC }\end{array}$ & Unknown & $5 \mathrm{~h}$ & $\begin{array}{l}\text { Immediate response with } \\
\text { isoflurane } \\
\text { Mild suppression of seizures with } \\
\text { nitrous/halothane }\end{array}$ & $\begin{array}{l}\text { Excellent } \\
\text { with } \\
\text { isoflurane }\end{array}$ & Unknown & Died \\
\hline
\end{tabular}




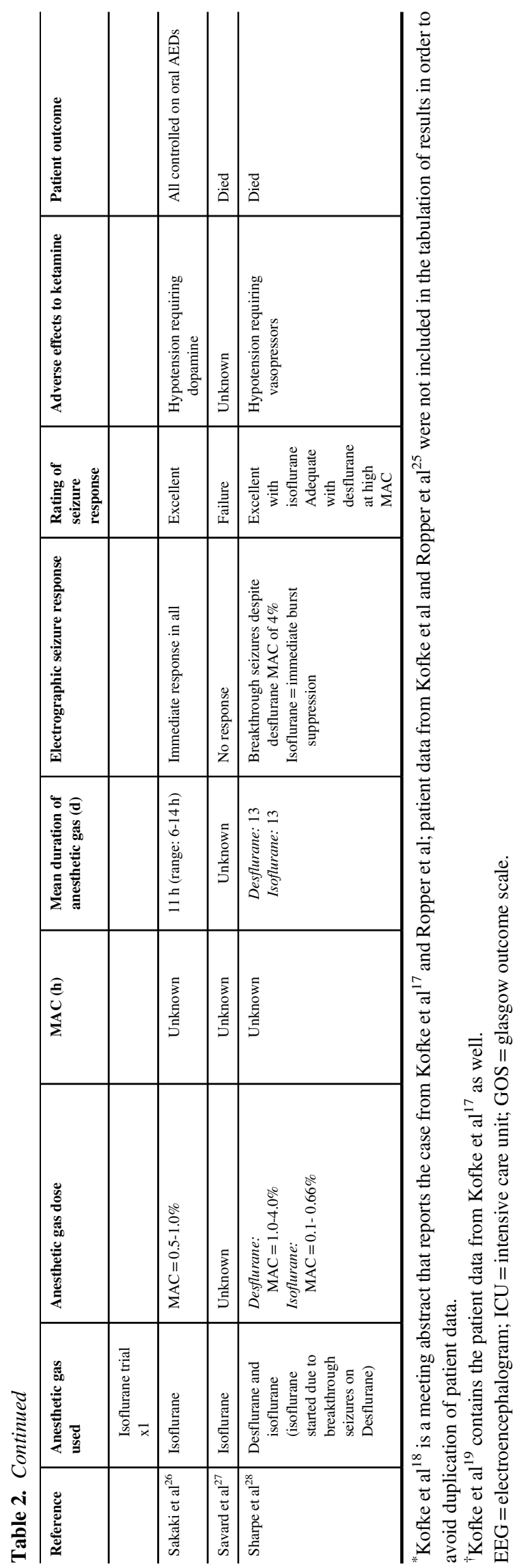

\section{Outcome}

Patient outcome was reported sparingly in most studies, with some documentation in 17 of the 19 articles. Two manuscripts failed to document outcome. ${ }^{11,12}$

The overall outcome of the patients was variable, with only four studies indicating patients $(n=4)$ returning home. ${ }^{16,17,20,21}$ The majority of patients suffered moderate to severe disability or died as a result of complications or uncontrollable seizures when taken off of inhalational anesthetics.

All studies describing treatment failure had poor outcomes. Within the three studies describing treatment failure, ${ }^{10,24,27}$ the final outcome was unknown in one patient, ${ }^{10}$ vegetative state in one,$^{24}$ and dead in one patient. ${ }^{27}$

\section{Level of Evidence for Inhalational Anesthetics}

Based on three independent reviewers, there were 19 studies reviewed, with all representing Oxford level 4 evidence in support of administering modern inhalational anesthetics for refractory seizures. Similarly, within the adult and pediatric population, all studies met the criteria for GRADE D level of evidence in support of the use of modern inhaled anesthetics for RSE.

Overall, we can recommend Oxford level 4 and GRADE D evidence for the use of isoflurane to control RSE. Given the lack of sufficient data for other inhalational anesthetics in the setting of RSE, we cannot make any formal comments on their efficacy. Summary of the level of evidence can be seen in Table 3.

\section{Discussion}

The use of modern inhalational anesthetic agents to control seizures has recently emerged as a salvage therapy in refractory cases. The numerous properties of inhalational anesthetics provide them with a unique means of modulating cerebral epileptogenicity. First, anesthetic gas is easily transported into the lipophilic environment of the central nervous system. Second, inhalational anesthetics are easily titrated to electroencephalographic response. ${ }^{23}$ Finally, anesthetic gas provides cerebral protection via inhibition of glutamate-mediated N-methyl-D-aspartate receptor excitotoxicity, while also activating $\mathrm{GABA}_{\mathrm{A}}$ receptors. ${ }^{38}$

Not all modern inhalational gases are equivalent, however. Sevoflurane has demonstrated in both animal and human studies ${ }^{39-41}$ to be pro-epileptogenic and therefore has not emerged as a potential therapy for RSE. Thus the antiepileptic properties of isoflurane and desflurane seem to be superior, potentially via more potent $\mathrm{N}$-methyl-D-aspartate inhibition. ${ }^{42}$ Similarly, the safety of prolonged administration provides both isoflurane and desflurane a potential advantage over sevoflurane and its predecessors halothane and enflurane. Xenon inhalational anesthetic gas has been sparingly reported in the literature and thus conclusive comments on its efficacy in RSE are limited.

The limitations of inhalational anesthetic treatments for RSE are few, but important. First, prolonged administration of fluorinated anesthetic gas has been demonstrated to lead to a rise in inorganic serum fluoride levels, of which the effects are undetermined. Recent animal literature indicates a dose-dependent increase in hepatic, renal, and pulmonary injury secondary to these fluorinated by products with isoflurane administration. Second, with sevoflurane administration, fluorinated byproducts have the potential to bind with carbon dioxide molecules, leading to toxic compounds that 
Table 3: Oxford and GRADE level of evidence

\begin{tabular}{|c|c|c|c|}
\hline Reference & Study type & Oxford $^{36}$ level of evidence & GRADE $^{37-42}$ level of evidence \\
\hline Alexopolous et al ${ }^{10}$ & Retrospective case series & 4 & $\mathrm{D}$ \\
\hline Azzopardi et $\mathrm{al}^{11}$ & Prospective cohort & 4 & $\mathrm{D}$ \\
\hline Demulder et $\mathrm{al}^{12}$ & Retrospective case series & 4 & $\mathrm{D}$ \\
\hline Fugate et al $^{13}$ & Retrospective case series & 4 & $\mathrm{D}$ \\
\hline Hilz et al ${ }^{14}$ & Retrospective case report & 4 & $\mathrm{D}$ \\
\hline Hilz et al ${ }^{15}$ & Retrospective case report & 4 & $\mathrm{D}$ \\
\hline Hughes et al ${ }^{16}$ & Retrospective case report & 4 & $\mathrm{D}$ \\
\hline Kofke et $\mathrm{al}^{17^{*}}$ & Retrospective case report & 4 & $\mathrm{D}$ \\
\hline Kofke et al ${ }^{18^{*}}$ & Retrospective case series & 4 & $\mathrm{D}$ \\
\hline Kofke et $\mathrm{al}^{19 \dagger}$ & Retrospective case series & 4 & $\mathrm{D}$ \\
\hline Kofke et $\mathrm{al}^{20}$ & Retrospective case report & 4 & $\mathrm{D}$ \\
\hline Lippert et al ${ }^{21}$ & Retrospective case report & 4 & $\mathrm{D}$ \\
\hline Meeke et al ${ }^{22}$ & Retrospective case report & 4 & $\mathrm{D}$ \\
\hline Mirsattari et $\mathrm{al}^{23}$ & Retrospective case series & 4 & $\mathrm{D}$ \\
\hline Robakis et $\mathrm{al}^{24}$ & Retrospective case report & 4 & $\mathrm{D}$ \\
\hline Ropper et al ${ }^{25^{*}}$ & Retrospective case report & 4 & $\mathrm{D}$ \\
\hline Sakaki et al ${ }^{26}$ & Retrospective case series & 4 & $\mathrm{D}$ \\
\hline Savard et al ${ }^{27}$ & Retrospective case report & 4 & $\mathrm{D}$ \\
\hline Sharpe et al ${ }^{28}$ & Retrospective case report & 4 & $\mathrm{D}$ \\
\hline
\end{tabular}

${ }^{*}$ Kofke et $\mathrm{al}^{18}$ is a meeting abstract that reports the case from Kofke et al ${ }^{17}$ and Ropper et al; patient data from Kofke et al and Ropper et al ${ }^{25}$ were not included in the tabulation of results in order to avoid duplication of patient data.

${ }^{\dagger}$ Kofke et $\mathrm{al}^{19}$ contains the patient data from Kofke et $\mathrm{al}^{17}$ as well.

impair renal function. ${ }^{43}$ Similar renal dysfunction has been reported with isoflurane administration. ${ }^{44}$ Third, the systemic cardiovascular effects of inhalation anesthetics need to be considered. Hypotension is a common side effect, typically requiring vasopressor to augment mean arterial pressures to within an acceptable range. Despite the cardiovascular depressant effect of inhalational gases, the effect seems to be less than compared with other standard intravenous anesthetic agents used in RSE. ${ }^{39,45,46}$ Isoflurane is not immune to this effect, with recent animal literature implicating a calcium mediated myocardial depression in high doses. ${ }^{47}$ Finally, isoflurane has recently been implicated in neurotoxicity and apoptotic-induced neuronal death in elevated concentrations. ${ }^{48,49}$ This is of concern, given the goal of its use in RSE is in prevention of neurological morbidity with prolonged/uncontrolled seizures. Thus, one will have to weigh the risks and benefits of its use in RSE before implementation.

Given the paucity of literature to date using inhaled anesthetic gases in the setting of RSE, we decided to perform this systematic review to provide a summary of the effect of modern inhalational gases (sevoflurane, isoflurane, desflurane, and xenon) on control of refractory seizures. Through our review, we identified 19 articles ${ }^{10-28}-16$ manuscripts and 3 meeting proceedings-using modern inhalational anesthetics to control refractory seizures. A total of 46 patients were described in these articles, with 28 being adult and 18 pediatric. The majority of the studies was retrospective case reports/series, ${ }^{10,12-28}$ with only 1 being prospective cohort study. ${ }^{11}$ Isoflurane was used in all but one study, ${ }^{11}$ where xenon was used. Desflurane was used with isoflurane in two studies. ${ }^{23,28}$ Seizure control with inhalation gas occurred in $92.9 \%$ and $94.4 \%$ of adult and pediatric patients, respectively, with the majority responding almost immediately upon gas administration. Burst suppression was achievable with titration. Desflurane was ineffective at achieving burst suppression, even at high MAC. Isoflurane was used as a salvage treatment in these cases. Isoflurane failed to control seizures in only 2 of 26 adult patients $(7.1 \%)$ and 1 of 13 pediatric patients $(7.7 \%)$ in which it was used. Xenon controlled seizures in all neonates with asphyxia seizures. Epileptic activity returned in most patients after cessation of inhalational anesthetics. In the secondary outcomes, only minimal adverse events were associated with inhalational anesthetic gas administration, with hypotension commonly described. Unfortunately, patient outcome data were too sparingly documented for any strong conclusion, though there was a trend to worse outcome in those whom failed therapy. All studies were an Oxford level 4 for quality, with all of adult and pediatric studies being a GRADE D level of evidence. A meta-analysis was not possible given the heterogeneous, retrospective nature of the majority of studies available. Thus, based on this review, we can currently provide Oxford level 4, GRADE D recommendations for the use of isoflurane for RSE. Given the paucity of data, similar conclusions for desflurane and xenon cannot be made at this time.

Important trends can be seen within our review. First, isoflurane appears effective ( $>90 \%$ responsiveness) in controlling RSE in a variety of underlying neuropathology; however, similar comments on desflurane and xenon cannot be made. 
Desflurane does appear less effective, however, requiring isoflurane salvage in the studies identified. Second, the antiepileptic effects of isoflurane are present even in those cases with RSE of up to and exceeding 2 months' duration. Third, prolonged administration of isoflurane, up to 85 days, does not seem to have any significant side effects. Hypotension was commonly described as the side effect in the studies identified, although this is also a common effect of intravenous anesthetics used in RSE. One study identified nonspecific MRI changes in the thalamus and cerebellum that potentially could be attributable to inhalational therapy. ${ }^{13}$ No reports of renal dysfunction were described. Caution must be taken, however, because the lack of adverse events with isoflurane administration is likely related to significant publication bias, reporting only those cases with positive outcomes on seizure control in RSE. Finally, both early (within 1 hour) and late implementation (at 85 days) of isoflurane seem effective in achieving burst suppression, thus supporting its potential efficacy at any point during the management of RSE.

Our review has significant limitations. First, the small number of studies identified, all with small patient populations, makes it difficult to generalize to all RSE patients. Second, the retrospective heterogeneous nature of the data makes it difficult to perform a meaningful meta-analysis, resulting in a strictly descriptive analysis. Third, the heterogeneity of prior treatments, time to inhalational anesthetic administration, and variable MAC and duration of therapy leave the data on seizure responsiveness difficult to interpret. It is even more difficult, on the basis of this data, to extrapolate to one's own clinical practice. Fourth, our comments on the efficacy of inhalation anesthetics are limited to isoflurane, given the small amount of data for desflurane and xenon in RSE at this time. Fifth, the potential for publication bias in the articles reviewed is high; it is likely that only those cases displaying positive results to inhalational anesthetic treatment have appeared in the literature. Sixth, even though burst suppression appears attainable in these cases of RSE, this treatment provides only a means to achieve seizure control, with a transition to oral medication still required. Seventh, the timing to administration of inhalational anesthetics was variable, and comments on the appropriate time to implementation cannot be made based on this review. Finally, the logistics of administering inhalational anesthesia within an intensive care unit has not been fully addressed. The majority of studies failed to indicate if an anesthetist was involved in treatment administration and if any issues were encountered in obtaining and operating the anesthetic machine. We believe that these important details may be major limiting factors in the widespread use of this technique by intensivists without an anesthesiology background. Given these limitations, there may be Oxford 4, GRADE D evidence to suggest the usefulness of inhalational anesthetics in RSE, but the data are heterogeneous at this point and further study is needed.

We believe this systematic review provides a good reference for the use of modern inhalational anesthetics in RSE. Consideration should be made for a future prospective study of inhalational anesthetics in RSE, given the heterogeneous data and significant publication bias identified within this review. The small number of cases identified in this review highlights the need for multicenter databases for RSE to better outline the role of nonconventional therapies.

\section{ConClusions}

There currently is Oxford level 4, GRADE D evidence to potentially support the use of isoflurane to achieve burst suppression for RSE in the adult and pediatric populations. Further prospective study of inhalational anesthetics in RSE is warranted.

\section{Disclosures}

FZ is a Health Sciences Center Foundation research recipient and received a research grant for the project on optic nerve sheath diameter.

\section{REFERENCES}

1. Brophy GM, Bell R, Claassen J, et al. Guidelines for the evaluation and management of status epilepticus. Neurocrit Care. 2012;17: 3-23.

2. Claassan J, Silbergleit R, Weingart SD, Smith WD. Emergency neurological life support. Neurocrit Care. 2012;17:S73-8.

3. Hunter G, Young B. Status epilepticus: a review, with emphasis on refractory cases. Can J Neurol Sci. 2012;39:157-69.

4. Deeb TZ, Maguire J, Moss SJ. Possible alterations in $\mathrm{GABA}_{\mathrm{A}}$ receptor signaling that underlie benzodiazepine-resistant seizures. Epilepsia. 2012;53(Suppl. 9):79-88.

5. Feng HJ, Mathews GC, Kao C, Macdonald RL. Alterations of GABA A-receptor function and allosteric modulation during development of status epilepticus. J Neurophysiol. 2008;99:1285-93.

6. Loscher W. Mechanisms of drug resistance in status epilepticus. Epilepsia. 2007;48(Suppl. 8):74-7.

7. Loscher W, Potscha H. Drug resistance in brain disease and the role of drug efflux transporters. Nat Rev Neurosci. 2005;6:591-602.

8. Rizzi M, Caccia S, Guiso G, et al. Limbic seizures induce P-glycoprotein in rodent brain: functional implications for pharmacoresistance. J Neurosci. 2002;22:5833-9.

9. Fujikawa DG. Prolonged seizure and cellular injury: understanding the connection. Epilepsy Behav. 2005;7(Suppl. 3):S3-11.

10. Alexopoulos A, Lachwani DK, Gupta A, et al. Resective surgery to treat refractory status epilepticus in children with focal epileptogenesis. Neurology. 2005;64:567-70.

11. Azzopardi D, Roberston NJ, Kapetanakis A, et al. Anticonvulsant effect of xenon on neonatal asphyxial seizures. Arch Dis Child Fetal Neonatal Ed. 2013;98:F437-9.

12. Demulder A, Ferster A, Pelc K, et al. Refractory status epilepticus and vacuolised bone marrow precursors: metabolic disease or treatment toxicity? J Pediatr Neurol. 2009;13:S127-8.

13. Fugate JE, Burns JD, Wijdicks EFM, Warner DO, Jankowski CJ, Rabinstein AA. Prolonged high-dose isoflurane for refractory status epilepticus: is it safe? Anesth Analg. 2010;110:1520-4.

14. Hilz MJ, Bauer J, Claus D, Stefan H, Neundorfer B. Isoflurane anesthesia in the treatment of nonconvulsive status epilepticus. J Neurol. 1992;239:135-7.

15. Hilz MJ, Erbguth F, Stefan H, Neundorfer B. Isoflurane for 7 days in refractory status epilepticus. Eur J Neurol. 1995;2:95-9.

16. Hughes DR, Sharpe MD, McLachlan RS. Control of epilepsia partialis continua and secondarily generalised status epilepticus with isoflurane. J Neurol Neurosurg Psychiatry. 1992;55:739-40.

17. Kofke WA, Snider MT, Young RSK, Ramer JC. Prolonged low flow isoflurane anesthesia for status epilepticus. Anesthesiology. 1985;62:653-6.

18. Kofke WA, Snider MT, O'Connell BK, et al. Isoflurane stops refractory seizures. Anesthesiology. 1987;67:A400.

19. Kofke WA, Young RSK, Davis P, et al. Isoflurane for refractory status epilepticus: a clinical series. Anesthesiology. 1989;71: 653-9.

20. Kofke WA, Bloom MJ, Van Cott A, Brenner RP. Electrographic tachyphylaxis to etomidate and ketamine used for refractory status epilepticus controlled with isoflurane. J Neurosurg Anesth. 1997;9:269-72.

21. Lippert MM. Isoflurane anesthesia for status epilepticus. S Afr Med J. 1989;75:350. 
22. Meeke RI, Soifer BE, Gelb AW. Isoflurane for the management of status epilepticus. DICP. 1989;23:579-81.

23. Savard M, Dupre N, Turgeon AF, Desbiens R, Langevin S, Brunet D. POLG mitochondrial disorder heralded by propofol infusion syndrome: a case report. Can J Neurol Sci. 2012;39(Suppl 3): G.09.

24. Mirsattari SM, Sharpe MD, Young B. Treatment of refractory status epilepticus with inhalational anesthetic agents isoflurane and desflurane. Arch Neurol. 2004;61:1254-9.

25. Robakis TK, Hirsch LJ. Literature review, case report, and expert discussion of prolonged refractory status epilepticus. Neurocrit Care. 2006;4:35-46.

26. Ropper AH, Kofke WA, Bromfield EB, Kennedy SK. Comparison of isoflurane, halothane, and nitrous oxide in status epilepticus. Ann Neurol. 1986;19:98-9.

27. Sakaki T, Abe K, Hoshida T, et al. Isoflurane in the management of status epilepticus after surgery for lesion around the motor area. Acta Neurochir (Wien). 1992;116:38-43.

28. Sharpe MD, Young GB, Mirsattari SM. Prolonged desflurane administration for refractory status epilepticus. Anesthesiology. 2002;97:261-4

29. Higgins JPT, Green S, eds. Cochrane Handbook for Systematic Reviews of Interventions, Version 5.1.0. Available from: http: handbook.cochrane.org.

30. Moher D, Liberati A, Tetzlaff J, Altman DG, PRISMA Group. Preferred reporting items for systematic reviews and meta-analysis: the PRISMA statement. Ann Intern Med. 2009;151:264-9.

31. Phillips B, Ball C, Sackett D, Straus S, Haynes B, Dawes M. Oxford Centre for Evidence-Based Medicine Levels of Evidence. Version 2009. Available from: http://www.cebm.net/?o=1025.

32. Guyatt GH, Oxman AD, Vist G, et al. Rating quality of evidence and strength of recommendations GRADE: an emerging consensus on rating quality of evidence and strength of recommendations. BMJ. 2008;336:924-6.

33. Guyatt GH, Oxman AD, Kunz R, et al. Rating quality of evidence and strength of recommendations: what is "quality of evidence" and why is it important to clinicians? BMJ. 2008;336:995-8.

34. Schünemann HJ, Oxman AD, Brozek J, et al. Grading quality of evidence and strength of recommendations for diagnostic tests and strategies. BMJ. 2008;336:1106-10.

35. Guyatt GH, Oxman AD, Kunz R, et al. Rating quality of evidence and strength of recommendations: incorporating considerations of resources use into grading recommendations. BMJ. 2008;336: $1170-3$.
36. Guyatt GH, Oxman AD, Kunz R, et al. Rating quality of evidence and strength of recommendations: going from evidence to recommendations. BMJ. 2008;336:1049-51.

37. Jaeschke R, Guyatt GH, Dellinger P, et al. Use of GRADE grid to reach decisions on clinical practice guidelines when consensus is elusive. BMJ. 2008;337:a744.

38. Engelhard K, Werner C. Inhalational or intravenous anesthetics for craniotomies? Pro inhalational. Curr Opin Anesth. 2006;19:504-8.

39. Gibert S, Sabourdin N, Louvet N, et al. Epileptogenic effect of sevoflurane: determination of the minimal alveolar concentration of sevoflurane associated with major epileptoid signs in children. Anesthesiology. 2012;117:1253-61.

40. Iijima T, Nakamura Z, Iwao Y, Sankawa H. The epileptogenic properties of the volatile anesthetics sevoflurane and isoflurane in patients with epilepsy. Anesth Analg. 2000;91:989-95.

41. Voss LJ, Sleigh JW, Barnard JPM, Kirsch HE. The howling cortex: seizures and general anesthetic drugs. Anesth Analg. 2008;107: 1689-90.

42. Solt K, Eger EI, Raines DE. Differential modulation of human $\mathrm{N}$-methyl-D-aspartate receptors by structurally diverse general anesthesia. Anesth Analg. 2006;102:1407-11.

43. Arici S, Karaman S, Dogru S, et al. Effects of isoflurane in an intoxication model: experimental study. Eur Rev Med Pharmacol Sci. 2013;17:1738-43.

44. Durak I, Oztürk HS, Dikmen B, et al. Isoflurane impairs antioxidant defence system in guinea pig kidney. Can J Anaesth. 1999;46: 797-802.

45. Filipovic M, Wang J, Michaux I, Hunziker P, Skarvan K, Seeberger MD. Effects of halothane, sevoflurane and propofol on left ventricular diastolic function in humans during spontaneous and mechanical ventilation. Br J Anaesth. 2005;94:186-92.

46. Marval P, Perrin ME, Hancock SM, Mahajan RP. The effects of propofol or sevoflurane on the estimated cerebral perfusion pressure and zero flow pressure. Anesth Analg. 2005;100:835-40.

47. Ding W, Li Z, Shen X, Martin J, King SB, Sivakumaran V, et al. Reversal of isoflurane-induced depression of myocardial contraction by nitroxyl via myofilament sensitization to $\mathrm{Ca} 2+$. J Pharmacol Exp Ther. 2011;339:825-31.

48. Kopp VJ, Jobson M. Does isoflurane or isoflurane plus hyperoxia induce apoptotic cell death? Anesth Analg. 2013;117:1023.

49. Creeley CE, Dikranian KT, Dissen GA, Back SA, Olney JW, Brambrink AM. Isoflurane-induced apoptosis of neurons and oligodendrocytes in the fetal rhesus macaque brain. Anesthesiology. 2014;120:626-38. 